\title{
Analytical characterization of ancient mortars from the archaeological roman site of Pisões (Beja, Portugal)
}

\author{
G. Borsoi ${ }^{a}$, A. Santos Silva ${ }^{b}$, P. Menezes ${ }^{c}$, A. Candeias ${ }^{d}, J$. Mirão ${ }^{e}$ \\ ${ }^{a}$ Heritage \& Architecture Section, Faculty of Architecture, TU Delft, Julianalaan 134, 2628 BL Delft, The Netherlands \\ ${ }^{\mathrm{b}}$ National Laboratory for Civil Engineering, Lisbon, Portugal \\ ${ }^{\mathrm{c}}$ Institute for Technological Research, IPT, São Paulo, Brazil \\ ${ }^{\mathrm{d}}$ Hercules Laboratory and Chemistry Department of the School of Science and Technology, University of Évora, Portugal \\ ${ }^{\mathrm{e}}$ Hercules Laboratory and Geosciences Department of the School of Science and Technology, University of Évora, Portugal
}

\section{H I G H L I G H T S}

- The Pisões archaeological site: an ancient roman construction in the Iberian Peninsula.

- Microstructural and chemical-mineralogical characterization of ancient mortars.

- Good state of conservation, strength and durability of these mortars.

- Careful selection of the materials and skilled craftsmanship.

\section{A R T I C L E I N F O}

\section{Article history:}

Received 28 June 2018

Received in revised form 11 January 2019

Accepted 30 January 2019

\section{Keywords:}

Roman mortars

Analytical characterization

Durability

Pozzolanic materials

\begin{abstract}
A B S T R A C T
The analytical characterization of mortar samples from the roman archaeological site of Pisões, located in Southern Portugal, were carried out by means of X-ray diffractometry (XRD), thermogravimetry (TGADTA), optical and electron scanning microscopy (SEM-EDS), potentiometry and combustion analysis.

The Pisões archaeological complex includes a villa rustica, characterized by well-preserved mosaics and thermal baths, as well as a mill and a mausoleum. Countryside villae epitomized the Romanization of the Iberian Peninsula for over six centuries (2nd century BCE-4th century CE). Nevertheless, most of the Roman villae identified in Portugal have not yet been systematically explored and studied.

This study provides valuable data on the construction materials and techniques used in Roman times in the Iberian Peninsula. The careful selection of raw materials and the use of natural and artificial pozzolanic materials can explain the favourable state of conservation, mechanical strength and long-term durability of these mortars.
\end{abstract}

() 2019 Elsevier Ltd. All rights reserved.

\section{Introduction}

The Roman occupation of the Lusitania province, which roughly includes modern Central and Southern Portugal and the Spanish region of Extremadura, began in the 2 nd century BCE and was consolidated mostly through the construction of villae rusticae (countryside villas). These structures epitomized the Romanization of the Iberian Peninsula for over six centuries. Over two hundred villae are identified in Portugal, as in the case of the villae of Milreu, São Cucufate or Cerro de Vila [1]. However, the construction technologies and building materials (i.e. renders and plasters) adopted in these archaeological sites have been poorly analyzed.

E-mail addresses: ssilva@Inec.pt (A. Santos Silva), prileal@ipt.br (P. Menezes), candeias@uevora.pt (A. Candeias),jmirao@uevora.pt (J. Mirão).
The archeological complex of Pisões was accidentally discovered nearby the Roman city of Pax Julia (currently known as Beja) in 1976. Archaeological evidence indicated a Roman occupation from the middle of the 1st century to the 4th century CE.

This villa rustica is divided into three parts: the owner house (pars urbana), the tilled land and the workers residence (pars rustica) and the rural warehouse (pars fructuaria). The pars urbana is composed of over forty rooms and partitions, as well as a central portico surrounded by columns [2]. Additionally, thermal baths with an exceptionally well-preserved system of underfloor heating (hypocaustum) and a largeswimming pool were identified near to the main building. Close to the villa, a small dam and a mill were identified [3]. Mosaics, marbles and mural paintings are remarkable vestiges that testify the high social status of the occupants and the prestige of the construction [4]. 
The review of previous research on roman mortars in the Iberian Peninsula points out that mortar compositions vary according to their use and function. Coating, lining or flooring mortars were mostly produced with calcitic (and rarely dolomitic) lime and mostly siliceous aggregate from local crushed stone and/or river sediment (e.g. quartz, feldspars, mica, schist, shale, granitic and greywacke lithoclasts). These mortars were identified in ancient houses and structures in the roman cities of Ammaia [5], Mértola [6], Tróia [7], Conímbriga [8,9], Lucus Augusti [10], Pollentia [11], Segobriga [12] and Augusta Emerita [13].

Waterproofing coatings, for example water-bearing and hydraulic structures, were produced by using lime mortars mixed with fine siliceous sand and relevant percentages of the so-called cocciopesto, i.e. artificial pozzolanic additions (crushed pottery or ceramic fragments). These coating mortars, identified as opus Signinum and often applied in multiple layers, were identified in hydraulic structures as tanks and thermal baths in Ammaia [5], Augusta Emerita [3], Conínbriga [8], Mértola [6], Segobriga [12] and Tróia [7]. Rarely, hydraulic lime (derived from limestone containing clay minerals) was identified as binder, as in the case of a roman house in Augusta Emerita [3].

In this paper, the analytical characterization of mortar samples from the roman archaeological site of Pisões, located in Southern Portugal, was carried out. This work aims at defining an adequate repair strategy and the formulation of compatible mortars for the Archaeological site of Pisões and, lastly, at improving the knowledge on ancient Roman building materials and techniques.

\section{Materials and methods}

\subsection{Samples}

On the basis of historical data, mortar samples were carefully collected in the most representative architectural structures of the Pisões archaeological site (Fig. 1a,b, Table 1). The construction technique mainly adopted in this site is the so-called opus incertum (irregular and randomly placed stones in a core of opus caementitium, i.e. a mortar prepared with aggregates, lime and pozzolanic/hydraulic additives). The thermal baths and the swimming pool present a wall structure in opus latericium (coarse-laid brickwork with a core of opus caementitium) and/or opus signinum (fragments of bricks mixed to a lime-based mortar).

\subsection{Characterization methodology}

The Determination of raw material composition is a starting point for the formulation of conservation mortars [8]. The characterization methodology carried out on the mortar samples comprises a range of complementary techniques, which aim at the identification of mortars characteristics (e.g. binder and aggregate) and the decay processes on the historical substrates [8,14-17].

XRD was performed on a Philips PW3710 X-ray diffractometer, working at $35 \mathrm{kV}$ and $45 \mathrm{~mA}$ and using Fe-filtered Co K $\alpha$ radiation $(\lambda=1.7903 \AA)$. Diffractograms were recorded in the range $3-74^{\circ}$ $2 \theta$, at increments of $0.05^{\circ} 2 \theta$ with a step time of $1 \mathrm{~s}$ per increment. The PANalytical X'Pert software was used to identify the mineral phases. Thermogravimetry and differential thermal analysis (TGA-DTA) were carried out in a Setaram simultaneous thermal analysis TGA 92 balance, under argon atmosphere $\left(3 \mathrm{~L} \mathrm{~h}^{-1}\right)$. Samples were previously dried at $40{ }^{\circ} \mathrm{C}$ in a drying oven for $48 \mathrm{~h}$. The thermal analysis was performed within the temperature range of $25-1000{ }^{\circ} \mathrm{C}$ at a heating rate of $10^{\circ} \mathrm{C} \mathrm{min}^{-1}$. The carbonate content (expressed in \% $\mathrm{CaCO}_{3}$ ) was calculated as follows:

$\% \mathrm{CaCO}_{3}=\left[\mathrm{P}_{\left(\mathrm{CO}_{2}\right)} \cdot \mathrm{MM}_{\left(\mathrm{CaCO}_{3}\right)}\right] / \mathrm{MM}_{\left(\mathrm{CO}_{2}\right)}$

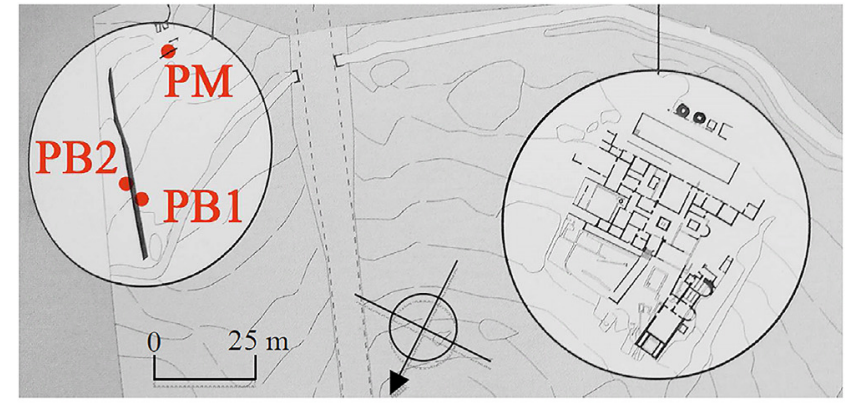

(a)

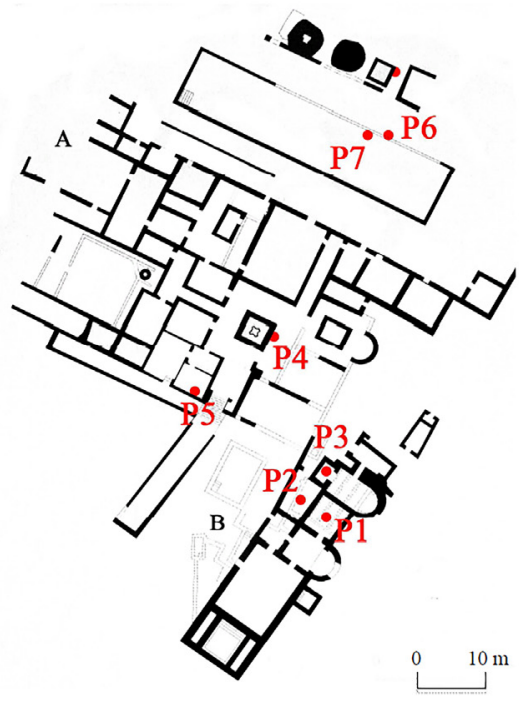

(b)

Fig. 1. a) Plan of the Pisões archeological site [9] and localization of the samples collected from the dam and the mill; b) detail of the pars urbana with (A) residential area and (B) thermal baths, and the localization of the collected samples.

where $\mathrm{P}_{(\mathrm{CO} 2)}$ is the mass loss in the temperature range $600-900{ }^{\circ} \mathrm{C}$ (corresponding to decarboxylation of calcium carbonate), $\mathrm{MM}_{(\mathrm{CaCO} 3)}$ is the molar mass of calcite and $\mathrm{MM}_{(\mathrm{CO} 2)}$ the molar mass of carbon dioxide.

Thin sections and polished surfaces of the mortar samples were prepared for microscopy observation. Mortar samples were dried for $12 \mathrm{~h}$ at $60^{\circ} \mathrm{C}$ and then vacuum impregnated with an epoxy resin (resin-hardener ratio 3:1). Impregnated cross sections were polished with abrasive $\mathrm{Al}_{2} \mathrm{O}_{3}$ slurries ( 15 and $9 \mu \mathrm{m}$ ) and diamond abrasive dispersions $(6,3,1$ and $0,25 \mu \mathrm{m})$.

The polished samples were observed with an Olympus SZH stereozoom microscope and an Olympus PMG3 optical microscope, whereas thin sections observations were performed with an Olympus BX60 polarized microscope. Images were digitally recorded with an Olympus DP-20 digital microscopy camera.

With the aim of defining the binder/aggregate ratio, portions of samples were carefully disaggregated and then attacked with an aqueous solution of hydrochloric acid (1:3) to separate the siliceous aggregate (insoluble residue) from the binder. This analysis was performed only in samples P2, P3, P4 and P8, due to the limited amount of sample available.

After filtration, chloride and sulfate contents were determined in the acid soluble fraction, respectively by potentiometric titration, as specified in EN14629 [18], and combustion analysis (in a Leco CS244), as specified by EN 196-2 [19]. The insoluble residue was weighed and sieved to determine the particle size distribution of the siliceous aggregates. Mechanical sieving was performed on 
Table 1

Identification and description of the samples and of the sampling sites.

\begin{tabular}{|c|c|c|c|c|}
\hline $\begin{array}{l}\text { Samples } \\
\text { Acronyms }\end{array}$ & Localization & Colour & $\begin{array}{l}\text { Construction } \\
\text { technique }\end{array}$ & Other relevant characteristics and empirical assessment of the conservation state \\
\hline P1 & $\begin{array}{l}\text { Warm bath room } \\
\text { (Caldarium) }\end{array}$ & $\begin{array}{l}\text { Reddish, light } \\
\text { brown }\end{array}$ & Opus latericium & $\begin{array}{l}\text { Very rich in crushed brick and ceramic materials; dark/grey aggregates; moderate } \\
\text { compaction and poor cohesion. }\end{array}$ \\
\hline P2 & $\begin{array}{l}\text { Furnace } \\
\text { (Praefurnium) }\end{array}$ & $\begin{array}{l}\text { Pale yellow, } \\
\text { cream }\end{array}$ & $\begin{array}{l}\text { Opus incertum/Opus } \\
\text { latericium }\end{array}$ & Mortar with mainly green and brown aggregates and white lumps; good compaction. \\
\hline P3 & $\begin{array}{l}\text { Clothing } \\
\text { (Apodyterium) }\end{array}$ & Pale brown & Opus incertum & $\begin{array}{l}\text { Rich in brick and siliceous (?) fragments, possibly with some clay/earths; low compaction } \\
\text { and poor cohesion. }\end{array}$ \\
\hline P4 & $\begin{array}{l}\text { Porch } \\
\text { (Peristilio) }\end{array}$ & $\begin{array}{l}\text { Very pale } \\
\text { brown }\end{array}$ & Opus incertum & Mortar with brick fragments and traces of black aggregates; good compaction and cohesion. \\
\hline P5 & Rooms & Pale brown & Opus incertum & $\begin{array}{l}\text { Mortar of brownish colour, similar to P3; different aggregates (black, green, red); low } \\
\text { compaction. }\end{array}$ \\
\hline P6 & $\begin{array}{l}\text { Swimming pool } \\
\text { (Natatio) }\end{array}$ & $\begin{array}{l}\text { Cream/ } \\
\text { yellow }\end{array}$ & Opus incertum & $\begin{array}{l}\text { Mortar with green, red and black aggregates; ceramic materials and lime lumps (?); high } \\
\text { compaction. }\end{array}$ \\
\hline P7 & $\begin{array}{l}\text { Swimming pool } \\
\text { (Natatio) }\end{array}$ & Whitish & Opus signinum & $\begin{array}{l}\text { Mortar with grey and dark aggregates; ceramic materials and white lime lumps (?); good } \\
\text { compaction and cohesion. }\end{array}$ \\
\hline P8 & $\begin{array}{l}\text { Mausoleum } \\
\text { (Sepolcrum) }\end{array}$ & Brownish & Opus incertum & $\begin{array}{l}\text { Mortar with a large variety of aggregates (green, red, yellowish), possibly including brick } \\
\text { fragments; moderate compaction and cohesion. }\end{array}$ \\
\hline PM & $\begin{array}{l}\text { Mill } \\
\text { (Molinum) }\end{array}$ & Cream & Opus incertum & $\begin{array}{l}\text { Mortar with brick fragments, dark and yellowish aggregates; low compaction and poor } \\
\text { cohesion. }\end{array}$ \\
\hline PB1 & Dam & Yellowish & Opus incertum & $\begin{array}{l}\text { Mortar with green and yellowish aggregates and white lime lumps (?); moderate } \\
\text { compaction. }\end{array}$ \\
\hline PB2 & Dam & Whitish & Opus incertum & Mortar with green and yellowish aggregates; moderate compaction and cohesion. \\
\hline
\end{tabular}

ISO 565 series sieves, with meshes of $4,2,1,0.5,0.250$ and $0.063 \mathrm{~mm}$ of diameter.

The simplified compositions of the mortars were calculated according to the "Jedrzejewska method" for ancient lime mortars [20]. Three components of the mortars are considered in this method: "sand" (corresponding to the insoluble residue in acid, IR), carbonates (\% mass of $\mathrm{CaCO}_{3}$, from TGA-DTA) and acid "soluble fraction" (soluble compounds in acid, without carbon dioxide formation). The "soluble fraction" content was calculated as follow:

\section{Soluble Fraction $=100-\Sigma($ IR + Carbonates $)$}

The binder:aggregate ratio was calculated considering the carbonates as binder, whereas the aggregate consists of the sand (insoluble residue in nitric acid) and the acid 'soluble fraction' [21].

SEM-EDS analyses were performed to observe the microstructure and texture of the mortars, as well as to detect the presence of neoformation products (e.g. re-precipitated carbonates, pozzolanic hydrated products) and soluble salts (e.g. $\mathrm{NaCl}, \mathrm{Na}_{2} \mathrm{SO}_{4}$ ). A Jeol JSM-6400 SEM, working at an acceleration voltage of $15 \mathrm{kV}$ and coupled with an Oxford energy dispersive (EDS) X-ray spectrometer, was used for the analysis; samples were sputtered with a gold-palladium film before analyses.

\section{Results and discussion}

\subsection{XRD analysis}

Table 2 illustrates the XRD mineralogical composition of the mortar samples. Results show that all the mortars present a calcitic aerial lime binder. Although Mg-based compounds are commonly identified in the raw materials of this region [5], no magnesium carbonate mineral phases (e.g. dolomite, magnesite or hydromagnesite) were detected in the analysis and thus used as binder.

Quartz and alkali feldspars are the main components of the mortars, associated with calcite, whereas kaolinite, sepiolite, mica, chlorite and amphiboles are accessory minerals. The presence of clay minerals (e.g. kaolinite, sepiolite, mica, and chlorite) can be detrimental in the mortars matrix, by favouring the penetration of water and/or reducing the porosity of the mortars (and thus triggering mechanical microtension in combination with salts) [22] However, these minerals were detected only in traces.
Samples P3, P5, PB1 and PB2 show similar mineralogical compositions, whereas samples $\mathrm{P} 6, \mathrm{~PB} 1$ and $\mathrm{PB} 2$ present also traces of aragonite, possibly due to dissolution and re-crystallization processes of the calcitic binder [17]. On the other hand, sample P1 presents only traces of calcite.

Sample P7 presents a peak at approximately $7.9 \AA$, attributed to monocarboaluminate $\left(\mathrm{C}_{4} \mathrm{ACH}_{11}\right)$. The formation of this hydraulic compound can be due to the reaction of the calcitic binder with aluminium-rich ceramic aggregates in a humid environment. However, hydraulic products as calcium silicate hydrate (CSH), calcium aluminate hydrates (CAH) or calcium aluminosilicate hydrates (CASH) may also exist in the form of gels or as low-crystallinity products [2], thus not detectable by XRD.

\subsection{TGA-DTA analysis}

The analysis of TGA-DTA curves, combined with the mineralogical composition of the samples (as seen in the previous section), allows to select the following temperature ranges: $25-120^{\circ} \mathrm{C}$, $120-200{ }^{\circ} \mathrm{C}, 200-600{ }^{\circ} \mathrm{C}$ and $600-900^{\circ} \mathrm{C}$, where significant weight loss occurred (Table 3 ).

The weight loss in the temperature range from 25 to $120^{\circ} \mathrm{C}$ is due to dehydration of hygroscopic or adsorbed water (i.e. onto phyllosilicates, Fig. 2a). The weight losses in this temperature range vary between $0.1 \%$ (P1) and 3.3\% (P6). The retention of physically bound water might be favoured by the presence of highly porous ceramic fragments [4], as in the case of samples P2, P4, P6 and P7.

No significant weight loss $(<1 \%)$ was observed in the range from $120^{\circ} \mathrm{C}$ to $200{ }^{\circ} \mathrm{C}$, which corresponds to the loss of crystallization water of hydrated salts (e.g. gypsum).

The weight loss at $200-600^{\circ} \mathrm{C}$ occurs due to the loss of chemically bound water (dehydroxylation) of clay minerals [23] (e.g. kaolinite, sepiolite and chlorite) and hydraulic products. These hydraulic compounds, such as calcium silicate or aluminate hydrates, are formed by the reaction of $\mathrm{Ca}(\mathrm{OH})_{2}$ with pozzolanic (e.g. brick and tile fragments) or volcanic (e.g. clay minerals or residual earth) materials.

These reactive materials were intentionally added to impart hydraulic properties (e.g. higher mechanical strength and lower permeability to water) to the respective mortars. In this weight loss range, a peak observed in sample P7 at nearly $220^{\circ} \mathrm{C}$ is attrib- 
Table 2

Mineralogical composition of the mortars assessed by XRD.

\begin{tabular}{|c|c|c|c|c|c|c|c|c|c|c|c|}
\hline \multirow[t]{2}{*}{ Crystalline compounds } & \multicolumn{11}{|c|}{ Samples } \\
\hline & P1 & P2 & P3 & P4 & P5 & P6 & P7 & P8 & PM & PB1 & PB2 \\
\hline Quartz & ++ & $+1++$ & $+/++$ & ++ & $+1++$ & + & ++ & +++ & $+1++$ & $+1++$ & $+1++$ \\
\hline Alkali feldspars & $++/+++$ & $+1++$ & $\mathrm{T}$ & $+1++$ & $\mathrm{T}$ & $+1++$ & $+/++$ & + & $++/+++$ & $+/++$ & $+1++$ \\
\hline Mica & $\mathrm{T} /+$ & - & $\mathrm{T} /+$ & $\mathrm{T}$ & $\mathrm{T} /+$ & $\mathrm{T}$ & - & + & - & $? / \mathrm{T}$ & - \\
\hline Kaolinite & - & $\mathrm{T} /+$ & $\mathrm{T}$ & - & $\mathrm{T}$ & $\mathrm{T}$ & - & + & $\mathrm{T} /+$ & $\mathrm{T}$ & $\mathrm{T}$ \\
\hline Chlorite & - & + & $\mathrm{T}$ & $\mathrm{T}$ & $\mathrm{T}$ & $\mathrm{T}$ & - & $\mathrm{T}$ & + & + & $\mathrm{T} /+$ \\
\hline Sepiolite & $\mathrm{T}$ & $\mathrm{T}$ & $\mathrm{T} /+$ & $\mathrm{T}$ & $\mathrm{T} /+$ & $? / \mathrm{T}$ & $\mathrm{T}$ & $\mathrm{T}$ & $? / \mathrm{T}$ & $\mathrm{T}$ & $\mathrm{T}$ \\
\hline Pyroxenes & - & $\mathrm{T}$ & $?$ & $\mathrm{~T}$ & $?$ & $\mathrm{~T}$ & - & $\mathrm{T}$ & $\mathrm{T}$ & $\mathrm{T}$ & $\mathrm{T}$ \\
\hline Amphiboles & + & $? / \mathrm{T}$ & $? / \mathrm{T}$ & $\mathrm{T} /+$ & $? / \mathrm{T}$ & $\mathrm{T}$ & + & - & + & $\mathrm{T}$ & $\mathrm{T}$ \\
\hline Calcite & $\mathrm{T}$ & +++ & $++/+++$ & $++/+++$ & $++/+++$ & $++/+++$ & $++/+++$ & $++/+++$ & $++/+++$ & $++/+++$ & $++/+++$ \\
\hline Aragonite & - & - & $?$ & - & $?$ & $\mathrm{~T}$ & - & - & - & $\mathrm{T}$ & $\mathrm{T}$ \\
\hline Hematite & + & $\mathrm{T}$ & $\mathrm{T}$ & $\mathrm{T}$ & $\mathrm{T}$ & $\mathrm{T}$ & $\mathrm{T}$ & $\mathrm{T}$ & $\mathrm{T}$ & - & - \\
\hline Halite & - & - & - & - & - & - & - & - & $\mathrm{T}$ & - & - \\
\hline $\mathrm{CCH}$ & - & - & - & - & - & - & $\mathrm{T}$ & - & - & - & - \\
\hline
\end{tabular}

+++ Dominant, ++ major, + minor, T traces, ? doubts in presence, - undetected, $\mathrm{CCH}$ - Calcium carboaluminate hydrate.

Table 3

Sample mass losses and calcium carbonate contents (\%) obtained by TGA.

\begin{tabular}{|c|c|c|c|c|c|c|}
\hline \multirow[t]{2}{*}{ Samples } & \multirow[b]{2}{*}{$25 \rightarrow 120$} & \multicolumn{3}{|c|}{ Temperature range $\left({ }^{\circ} \mathrm{C}\right)$} & \multirow[t]{2}{*}{ Loss of ignition } & \multirow[t]{2}{*}{$\% \mathrm{CaCO}_{3}{ }^{1}$} \\
\hline & & $120 \rightarrow 200$ & $200 \rightarrow 600$ & $600 \rightarrow 900$ & & \\
\hline P1 & 0.1 & 0.1 & 0.3 & 0.2 & 0.70 & 0.5 \\
\hline $\mathrm{P} 2$ & 2.5 & 0.2 & 3.7 & 20.1 & 26.4 & 41 \\
\hline P3 & 2.3 & 0.1 & 3.4 & 12.8 & 18.9 & 26 \\
\hline $\mathrm{P} 4$ & 2.9 & 0.8 & 3.5 & 11.4 & 18.7 & 28 \\
\hline P5 & 1.6 & 0.3 & 2.9 & 11.3 & 16.1 & 26 \\
\hline P6 & 3.3 & 0.9 & 3.6 & 11.7 & 19.7 & 27 \\
\hline P7 & 3.1 & 0.9 & 3.2 & 16.5 & 23.8 & 38 \\
\hline P8 & 2.3 & 0.8 & 3.9 & 9.4 & 16.6 & 23 \\
\hline PM & 0.8 & 0.6 & 2.9 & 10.3 & 14.0 & 23 \\
\hline PB1 & 2.6 & 0.5 & 3.7 & 14.7 & 24.9 & 33 \\
\hline PB2 & 2.2 & 0.6 & 4.4 & 18.6 & 25.9 & 42 \\
\hline
\end{tabular}

${ }^{1}$ Calculated as described in Eq. (1) (Section 2.2).

uted to the decomposition of monocarboaluminate (Fig. 2b), in accordance with XRD analysis. This compound is known to confer hydraulic properties and higher plasticity to the mortar [24,25].

The weight loss between 450 and $550{ }^{\circ} \mathrm{C}$ is attributed to the decarbonation of magnesite $\mathrm{MgCO}_{3}$ [5,24]. The percentage of magnesium carbonate is low in all the analysed samples $(\leq 1 \%)$, and slightly more significant (>2\%) only in samples P2, PB1 and PB2. This low amount of magnesite is hardly detected by XRD [5], explaining the results observed in Section 3.1.

Additionally, a mass loss at $220^{\circ} \mathrm{C}$, attributed to the decomposition of another calcium aluminate (calcium monocarboaluminate), can be observed in sample P7 (Fig. 2b), in accordance with XRD analysis. This compound is also known to confer hydraulic properties and higher plasticity to the mortar.

Finally, the weight loss between 600 and $900{ }^{\circ} \mathrm{C}$ corresponds to the loss of $\mathrm{CO}_{2}$ as a consequence of the decomposition of calcium carbonate [11] and thus enables the determination of the $\mathrm{CaCO}_{3}$ content within the sample.

Mortars P3 to P6, P8 and PM have similar carbonated lime content (23-28\%, in mass), whereas a remarkably higher binder content (33-42\%) was identified in mortars P2, P7, PB1 and PB2. On the other hand, it can be observed that sample P1 has a minimal calcite content.

It is generally assumed that lime mortars (or non-hydraulic mortars) are typically characterised by less than $3 \%$ of chemically bound water of the hydraulic components and high $\mathrm{CO}_{2}$ amount, whereas mortars with higher amounts of water bound and proportionally small quantities of $\mathrm{CO}_{2}$ are considered hydraulic $[5,11,26,27]$. Mortars P3, P5, P8 and PM present weight loss at $200-600{ }^{\circ} \mathrm{C}$ lower than $3 \%$, however, their small quantity of $\mathrm{CO}_{2}$ cannot exclude the presence of hydraulic products.
A significant classification of the mortar nature can be obtained by plotting the $\mathrm{CO}_{2}$ to structurally bound water ratio (i.e. the inverse trend of hydraulicity of mortars) in relation to $\mathrm{CO}_{2}$ percentage, as shown in Fig. 3.

The samples can be identified within three main groups in the plot: group A (including mortars P3, P5, P6, P8 and PM), with a percentage of $\mathrm{CO}_{2}$ between $10 \%$ and $13 \%$ and $\mathrm{CO}_{2} / \mathrm{H}_{2} \mathrm{O}$ ratio between 2.5 and 4; group B (samples P4 and PB1), with a percentage of $\mathrm{CO}_{2}$ between $14 \%$ and $15 \%$ and $\mathrm{CO}_{2} / \mathrm{H}_{2} \mathrm{O}$ ratio between 4 and 4.5 ; group $\mathrm{C}$ (composed of mortars P2, P7, PB2) with a percentage of $\mathrm{CO}_{2}$ between $16.5 \%$ and $19 \%$ and $\mathrm{CO}_{2} / \mathrm{H}_{2} \mathrm{O}$ ratio between 4.3 and 5.5 .

Additionally, the graph of Fig. 3 confirms that sample P1 is not a mortar but rather a raw material (brick fragment), in accordance with XRD analysis.

The similarities between the thermograms of samples P3, P5, P8 and PM can be attributed to their similar functionality (finishing mortars in the clothing, mausoleum and mill), whereas those of mortars P2, P7, PB1 and PB2 are typical of coating mortars with hydraulic properties (used in the thermal bath, swimming pool and dam).

\subsection{Chemical analysis and grain size distribution}

The simplified chemical analysis of the samples, presented in Table 4 , can provide valuable information on the weathering and state of conservation of the mortars.

No significant amounts of potential alteration compounds (i.e. chlorides and/or sulphates) were detected, in accordance with XRD and TGA-DTA analyses. 

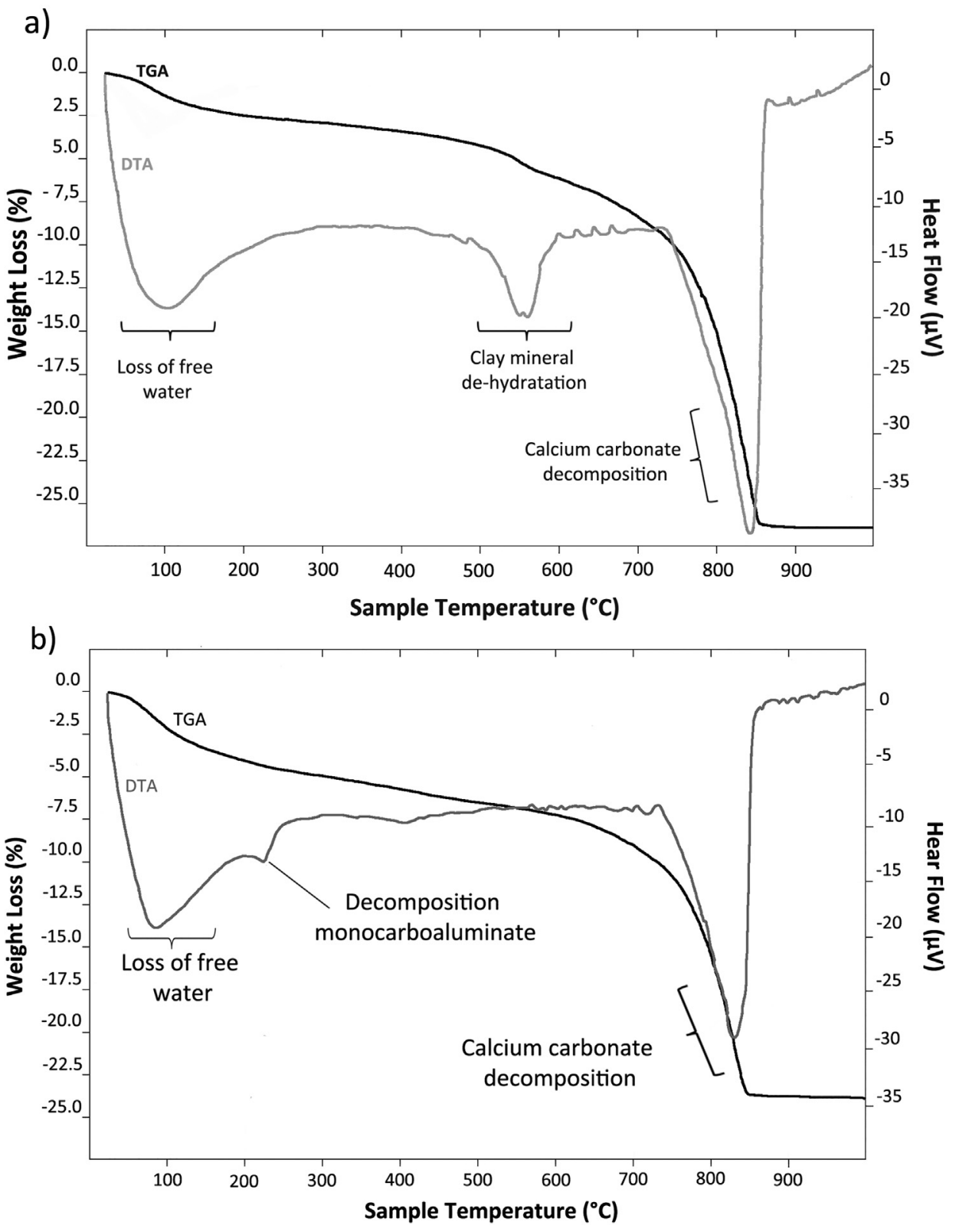

Fig. 2. TGA-DTA curves of mortars: a) P2 and b) P7.

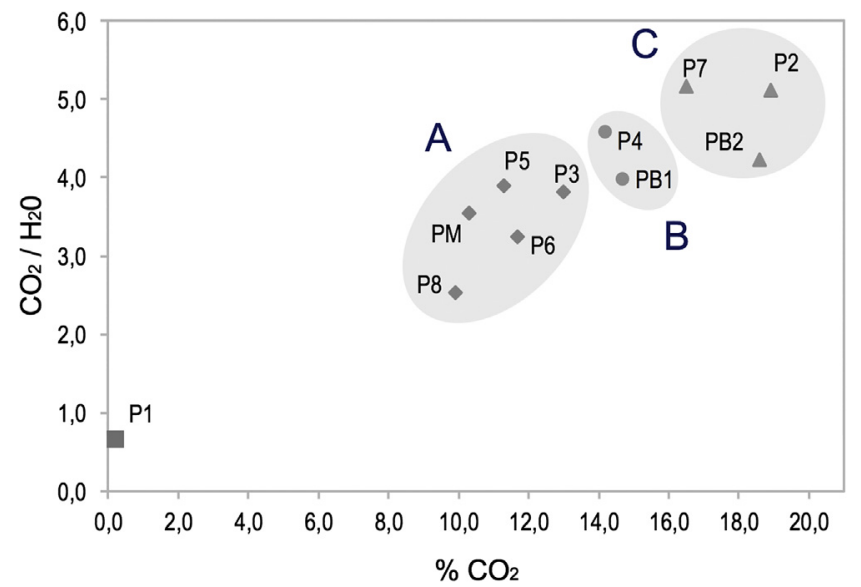

Fig. 3. $\mathrm{CO}_{2}$ to structurally bound water ratio in relation to $\% \mathrm{CO}_{2}$ of the different samples.
Table 4

Simplified chemical composition of the mortars (\% wt).

\begin{tabular}{llll}
\hline Mortar Identification & Insoluble residue & Sulphates $\left(\mathrm{SO}_{3}\right)$ & Chlorides $\left(\mathrm{Cl}^{-}\right)$ \\
\hline P2 & 46 & 0.14 & $<0.01$ \\
P3 & 64 & 0.13 & $<0.01$ \\
P4 & 60 & 0.15 & 0.01 \\
P8 & 68 & 0.18 & 0.02 \\
\hline
\end{tabular}

The grain size distribution of the aggregates (Fig. 4) reveals that samples P2, P3 and P8 are similar, with unimodal distribution curves and grain size generally coarser than $1 \mathrm{~mm}$ (about $70 \%$ by weight). However, P2, P4 and P8 present coarser aggregates ( $\simeq 45 \%$ aggregates $\geq 5 \mathrm{~mm}$ ) compared to $\mathrm{P} 3$ ( $<35 \%$ ).

The use of aggregates with different size can be attributed to the required functionality of the relative mortars. In fact, coarse fragments of stone and crushed bricks were used in samples P2 (collected from the furnace of the thermal bath), whereas coarse 


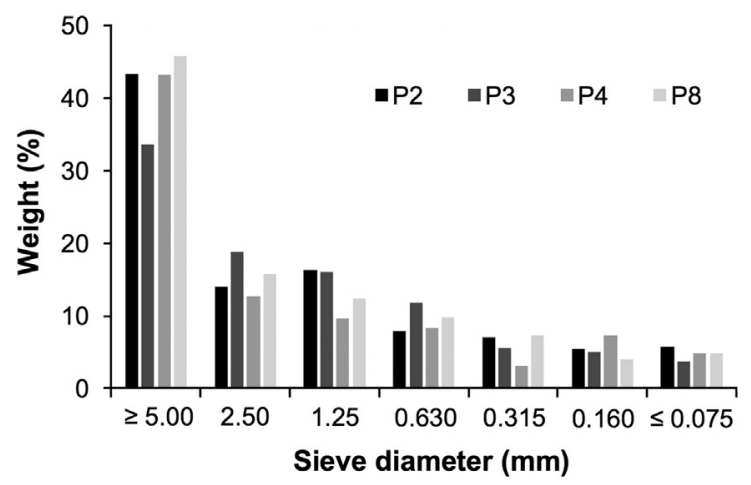

Fig. 4. Grain-size distribution of the aggregates in mortar samples P2, P3, P4 and P8.

fragments of crushed stone were adopted in samples P4 and P8 (used in the porch and mausoleum, respectively). Conversely, mortar P3, applied in the apodyterium (the dressing room of the thermal bath), was prepared with slightly finer aggregates.

\subsection{Optical microscopy}

\subsubsection{Stereozoom observations}

Microscopical observations of the polished cross-sections showed the heterogeneity of the samples and the wide variety of the aggregates in terms of mineralogical nature, grain size and shape.

Sample P1 presents a compact reddish matrix with fragments of dark igneous rocks and siliceous grains (Fig. 5a).

Mortar P2 (Fig. 5b), like PB1 (Fig. 5c) and PB2, presents green shale (and/or schist), lime lumps and siliceous and dark aggregates. The absence of binder cracks in the lumps indicates a low shrinkage, suggesting that the raw limestone used for the production of the binder was soft-burned. Additionally, highly reactive lime (i.e. quick reaction with water during slaking) with good plasticity and workability was obtained by using lower burning temperature [28].

Samples P3 (Fig. 6a) and P5 illustrate a clayey aspect (which can be attributed to the addition of residual earth within the mortars) with siliceous and dark aggregates.

Mortar samples P4, P6 (Fig. 6b), and P7 (Fig. 6c) present remarkable quantity of ceramic fragments and siliceous aggregates. Mortar P7 was collected from the swimming pool, thus the addition of artificial pozzolanic additives can be attributed to its hydraulic properties, in accordance with TGA-DTA results (Section 3.2). As a matter of fact, crushed bricks or fragments of ceramic materials have been used as aggregates in the manufacturing of lime mortars and plasters since ancient times. In fact, these reddish colour mortars, identified as horasan in Turkey, surkhi in India, homra in Arabic countries and opus signinum in Roman times [29], increase renders impermeability and hydraulicity [3,12]. This typology of mortars was thus widely used by Roman builders for tanks, aqueducts and in general water-bearing structures, as confirmed also by other works on Roman structures in the Iberian Peninsula $[3,5,7,8,12,30]$. Due to the lack of natural pozzolanic materials (e.g. pumice or volcanic ashes) in Portugal, there was a widespread use of this technique and the main archaeological sites present walls covered by opus signinum [8].

Microscopic analysis confirmed that the mortars with abundant ceramic fragments (e.g. P2, P4, P7) are unaltered and present a favourable state of conservation [28]. Additionally, the introduction of large ceramic particles favoured the introduction of air and thus a more efficient carbonation [8].
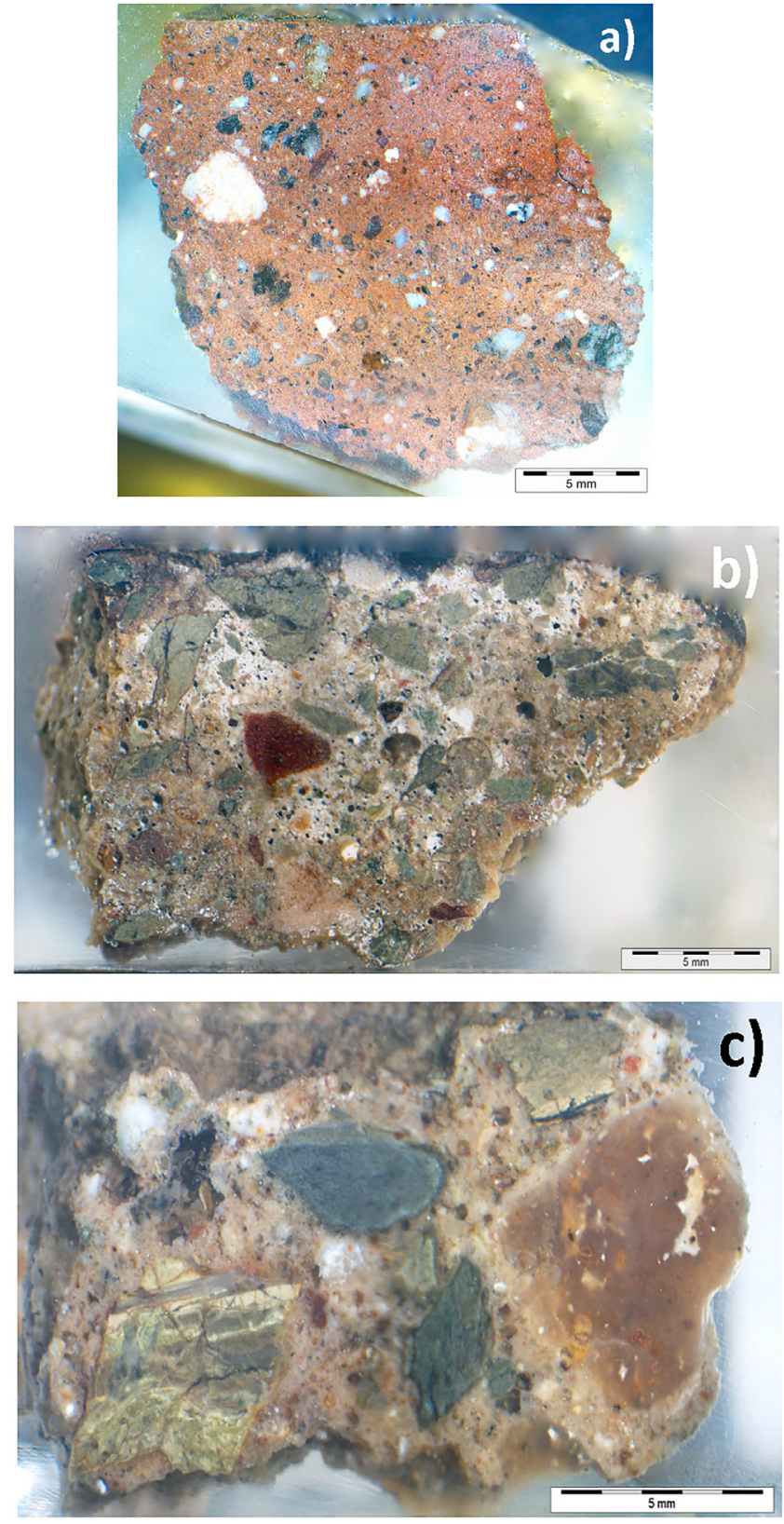

Fig. 5. Images at stereozoom microscope of polished sections mortar samples P1 (a), P2 (b) and PB1 (c).

Mortar samples P8 and PM show a clayey heterogeneous aspect, with wide aggregates variety in composition, size, shape and colour (e.g. dark, green, red). Finally, traces of biological colonization can be observed on the surface of all the mortar samples.

\subsubsection{Petrographic observations}

Petrographic microscopy was used to collect additional data on the aggregates employed and to identify pozzolanic additives and neoformation products.

All samples present siliceous minerals and rocks, namely quartz, quartzite, pyroxenes (P1, P2, PB1) and amphiboles (P1, P3, P6, PB1). Phyllosilicates minerals, such as chlorite (Fig. 7b) and mica (Fig. 7d), were identified in mortars P2, P3, and PB1, whereas hematite and ceramic fragments were found in all mortars (except for P5 and PM). Chlorites, which derived mainly from the alteration of biotite (a mineral of the granites [5]), are con- 

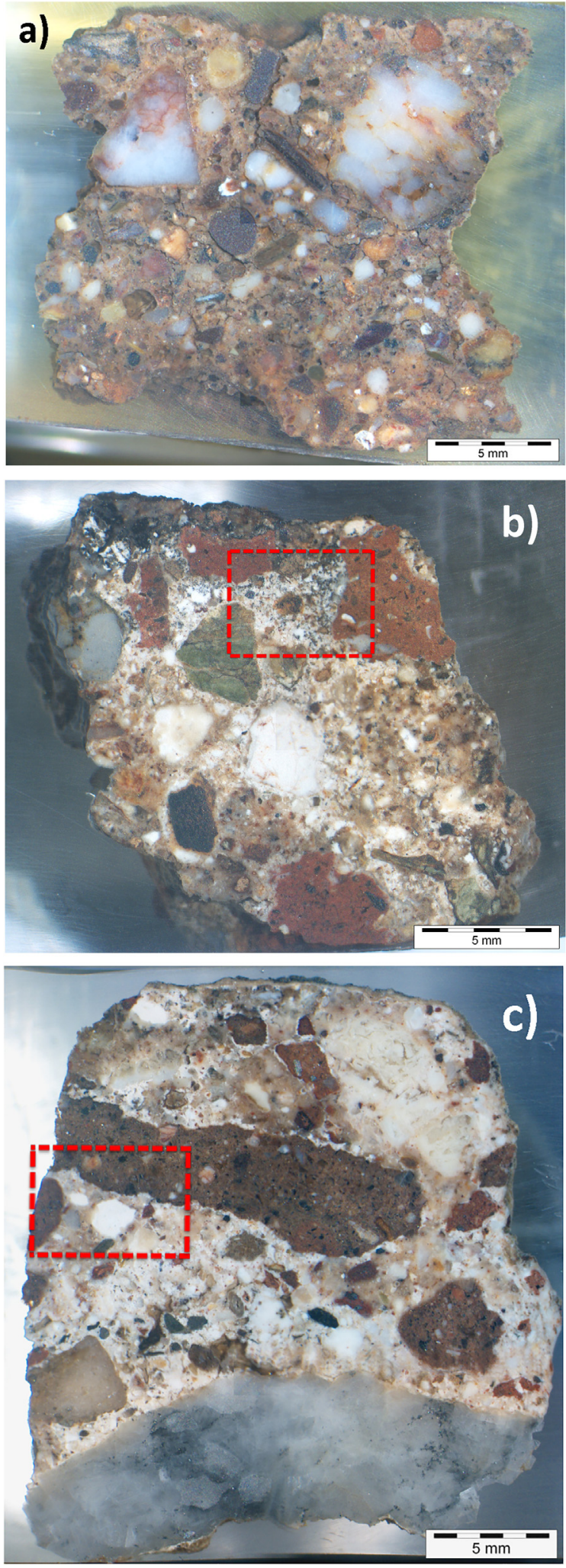

Fig. 6. Images at stereozoom microscope of the polished sections mortar samples P3 (a), P6 (b) and P7 (c). The dotted areas in b and c refer to the micropictures in Fig. $9 \mathrm{c}$ and $10 \mathrm{a}$, respectively.

stituents of the weathered igneous and metamorphic rocks that were identified by stereozoom observations.

Additionally, other samples present granitoid rocks (P1, P6) (Fig. 7a) and shale (P3, P6, P8, PB1) (Fig. 7c) [30,31] as aggregates.
The thin section observations of the mortars with crushed ceramic (mostly in mortars P2, P4, P6, P7, and traces in samples P8 and $\mathrm{PB} 1)$ reveal the occurrence of reaction rims around the brick fragments (Fig. 7d), attributed to the migration of $\mathrm{SiO}_{2}, \mathrm{Al}_{2} \mathrm{O}_{3}$ and $\mathrm{Fe}_{2} \mathrm{O}_{3}$ from the ceramic fragments to the calcitic binder and the consequent formation of CSH and CASH gels [2]. The addition of highly porous brick fragments increases water retention, which is fundamental for the formation of pozzolanic products over time [3].

Additionally, well-rounded lime lumps were observed in all samples (except for sample P1). This feature is attributed to the dry slaking of lime [32], i.e., slaked with a minimum amount of water to convert $\mathrm{CaO}$ into $\mathrm{Ca}(\mathrm{OH})_{2}$. This carelessness in the lime extinction $[6,26]$ can explain also the poor cohesion and widespread microcracking of mortars P3 and P5, formulated with siliceous aggregates, which have lower reactivity when compared to ceramic fragments.

On the other hand, mortars P2 and P6 present a homogeneous distribution of the calcitic binder and a high compactness, which can be explained also by the formation of pozzolanic products. Coarse aggregates are oriented parallel to the surface, probably as a results of the careful hand-made compaction of these mortars [33].

Poorly calcined carbonate rock fragments were observed in the heterogeneous matrix of mortars P3 and PB1. In addition, fragments of volcanic or plutonic igneous rocks (Fig. 7e) were identified in mortars P2, P6, PB1 and PB2. As a matter of a fact, certain clayey sands, which contain high proportions of schist, basalt, feldspar and/or mica, can have mildly pozzolanic properties. Green schist, for example, is a metamorphosed clay and thus contains silica and magnesium aluminate, which can confer hydraulic properties to the mortars.

The quartzitic aggregates present a sub-angular to rounded morphology, which suggests a possible fluvial origin.

Crushed ceramic fragments, which were likely fired at low temperature in order to ensure a higher reactivity with the other components [13], probably derived from different waste materials. In fact, some fragments present wider pozzolanic reaction rims at the aggregate-binder interface, indicating that these fragments were possibly obtained from the grinding of reused buildings materials (e.g. bricks or roof tiles), a common practice of roman builders. Conversely, some fragments have a more confined pozzolanic reaction rim and a dark layer at one side of the fragment, probably as a consequence of specific treatments (such as glazing or smoothing), indicating its probable origin (i.e. domestic pottery).

The identification of minor mineral phases and rocks (i.e. amphiboles, igneous rocks such as granites, and shale) can help identify the origin of the aggregates. The observation of the thin sections (in accordance with stereozoom observations and XRD analysis) has shown that the mineralogical composition of the aggregates is related to the local geology [5]. In fact, the aggregates used for the mortars probably derive from an area nearby the villa, closed to the Guadiana river, as shown in the geological map of the Beja district (Fig. 8). Previous studies on other Roman mortars in the same region $[7,30,34]$ confirm the use of fluvial aggregates from the Guadiana river bank, located at above $20 \mathrm{~km}$ East of the Pisões archaeological site.

\subsection{SEM-EDS analyses}

SEM-EDS analysis provides additional information on the morphology and chemical composition of the mortars.

Mortar samples P2, P4 and P7 mortars (applied respectively in the thermal baths, external porch and swimming pool) present a compact microstructure and a remarkably high amount of ceramic fragments. As a matter of a fact, mortars with pozzolanic additions ensure waterproofing properties and higher mechanical strength 

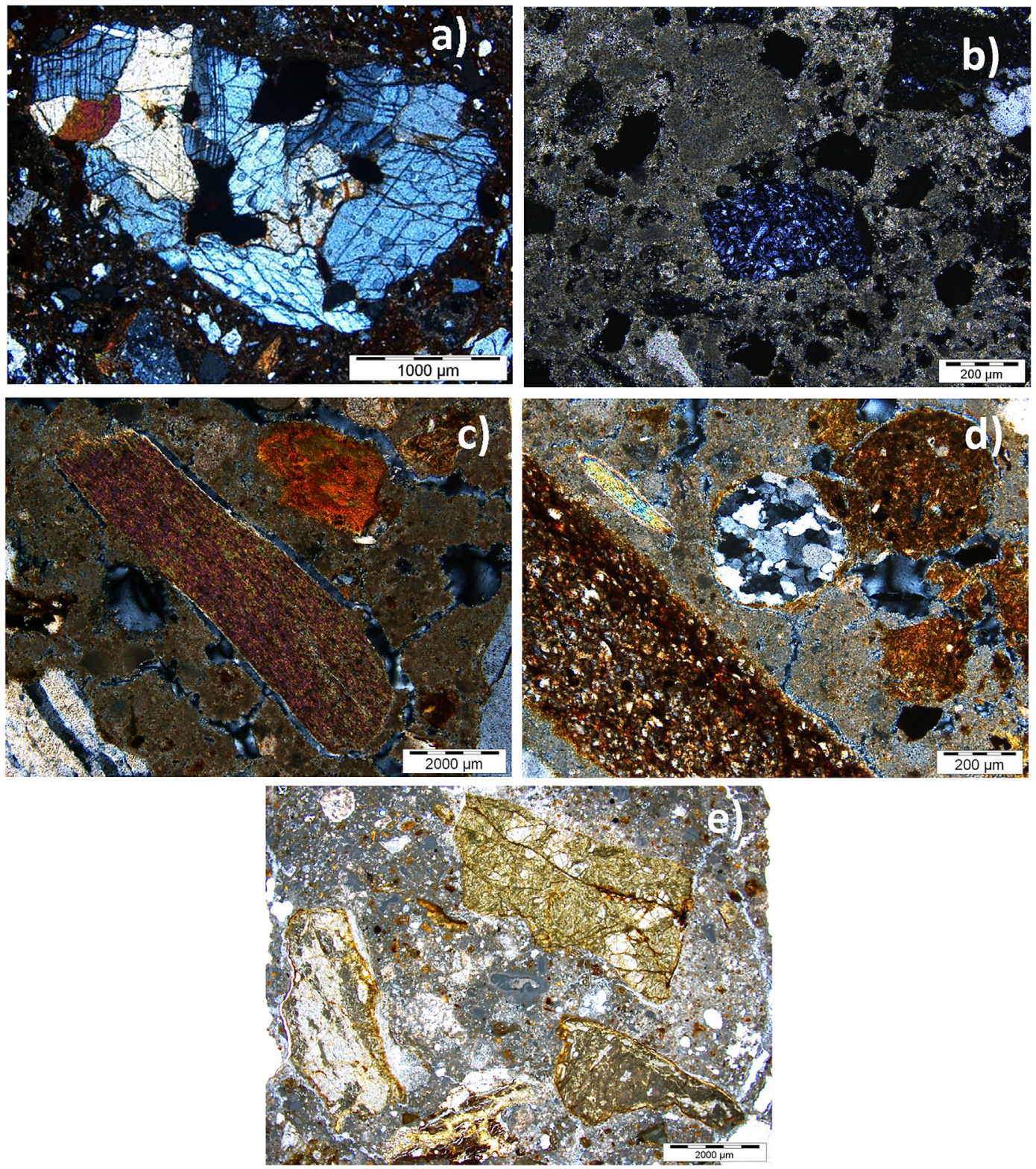

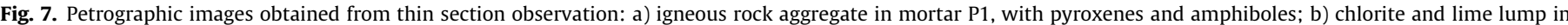

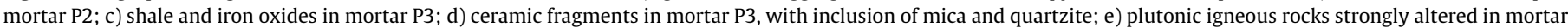
P6.

and durability (e.g. resistance to salt decay and environmental loadings), when compared to ordinary lime-based mortar [26,35].

The pozzolanic activity is promoted by the high content of calcium-poor clay minerals (generally aluminates and silicates) of the ceramic powder, which was probably fired at low temperature [24]. In fact, these pozzolanic materials provide alumina and silica to an alkaline environment, inducing reactions with the formation of calcium silicate hydrates (CSH) and/or calcium aluminosilicate hydrates (CASH) at the lime binder-ceramic interface, as observed in sample P7 (Fig. 9a and b).

The formation of neoformation products ( $\mathrm{CSH}$ and $\mathrm{CASH}$ ) at the ceramic fragments interface is also confirmed by colour superposition of the elemental maps of silicon, calcium and aluminium of mortar P6 (Fig. 9c) and observing the relative EDS spectrum (Fig. 9d). Carboaluminates are also formed at high $\mathrm{Al}_{2} \mathrm{O}_{3}$ and lime concentration in the pores of the pozzolanic mixtures, as confirmed by XRD analysis (Section 3.1) [25].
Additionally, significant amounts of magnesium and silicon were observed at the binder-aggregate interfaces, as in the case of mortar P7 (elemental X-ray map of Mg, Fig. 10a), which can indicate the formation of magnesium silicate (relative EDS spectrum, Fig. 10b).

The binder matrix in these mortars is fully carbonated and generally homogeneously distributed. Although minor amounts of magnesium were detected in samples P6, P7 and P8, the binder of the mortars is mainly composed of calcium, which is indicative of the use of a calcitic air lime. Lime lumps, considered as the closest indicator of the lime used at the moment of mortar preparation [5], are also composed mostly of calcium. Hence, all mortars were produced with non-hydraulic lime, and the hydraulicity of part of the mortars is due to the addition of ceramic (in agreement with Roman technological records) [28].

The particles of the binder present heterogeneous morphologies, attributed to different calcite formation processes. In fact, pri- 


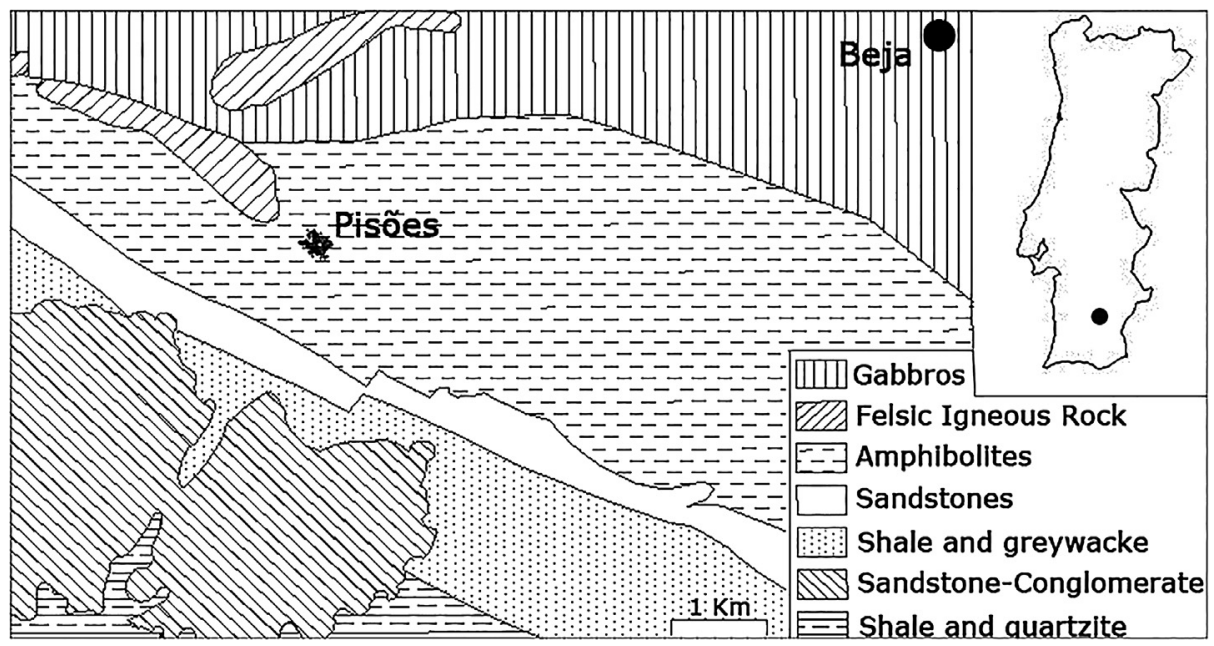

Fig. 8. Simplified geological map of the south-west area of the Beja district, showing the location of the Pisões archealogical site.
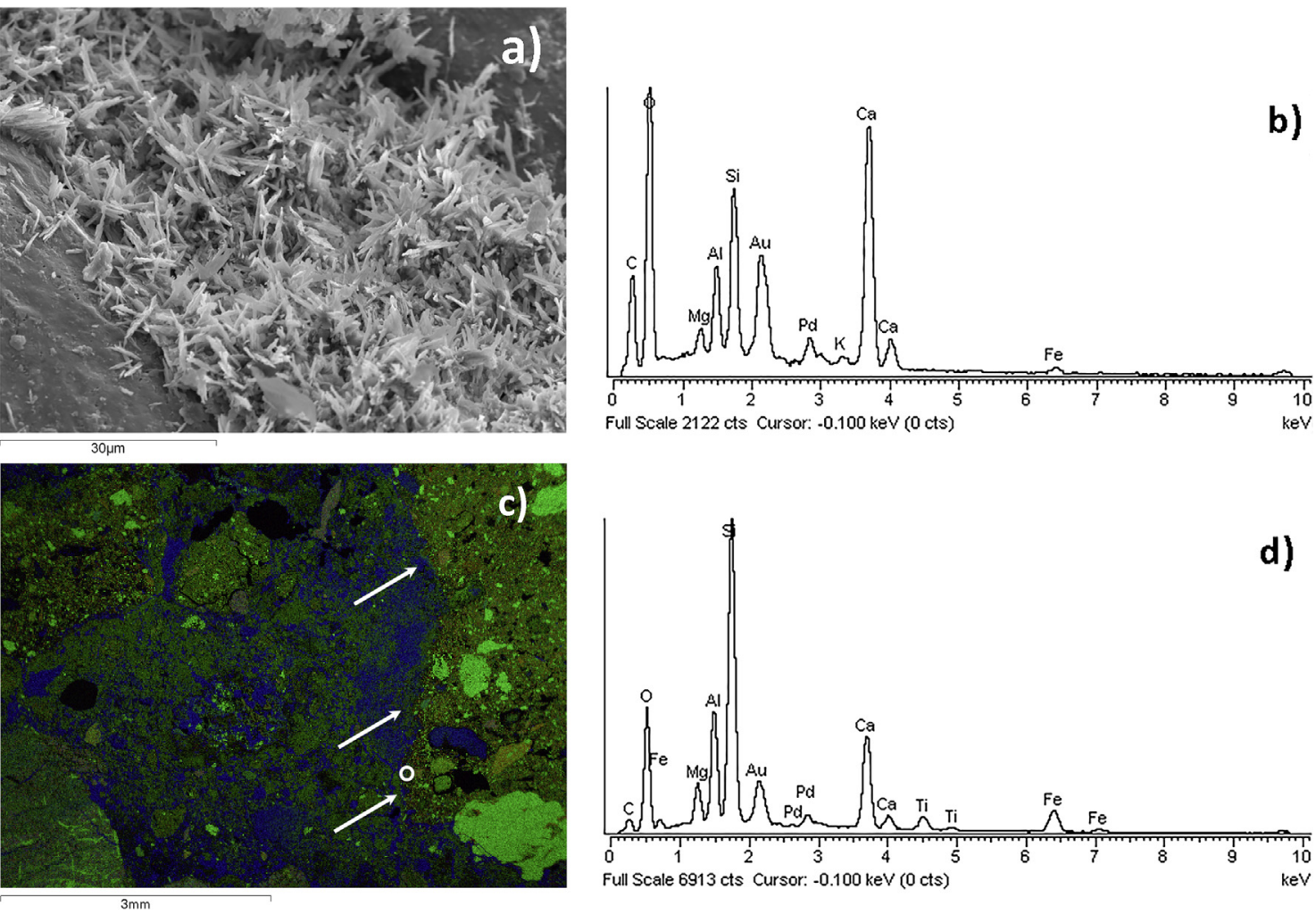

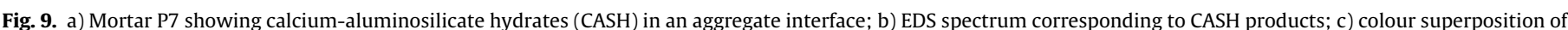

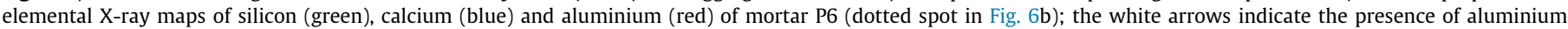

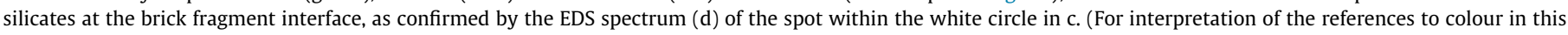
figure legend, the reader is referred to the web version of this article.)

mary hydromorphic calcite crystals (i.e. calcite and aragonite, as confirmed by XRD analysis) formed from the original raw materials can be found, as well as calcite micro-grains formed by secondary crystallization. Additionally, recrystallized calcium carbonate (formed by dissolution-recrystallization process of $\mathrm{CaCO}_{3}$, when exposed to weathering) can be identified in the mortar pore network (Fig. 10c, d). Recrystallized $\mathrm{CaCO}_{3}$ partially fills the pore and concentrates around the aggregates.

\subsection{Mortars composition}

The simplified compositions of the mortars were calculated according to the method described in Section 2.2 and are reported in Table 5.

The binder/aggregate ratios are in accordance with results reported in other studies [7]. Nevertheless, this method cannot distinguish the binder from the carbonate aggregate grains. This can explain the high binder/aggregate ratio obtained in mortar P2. 

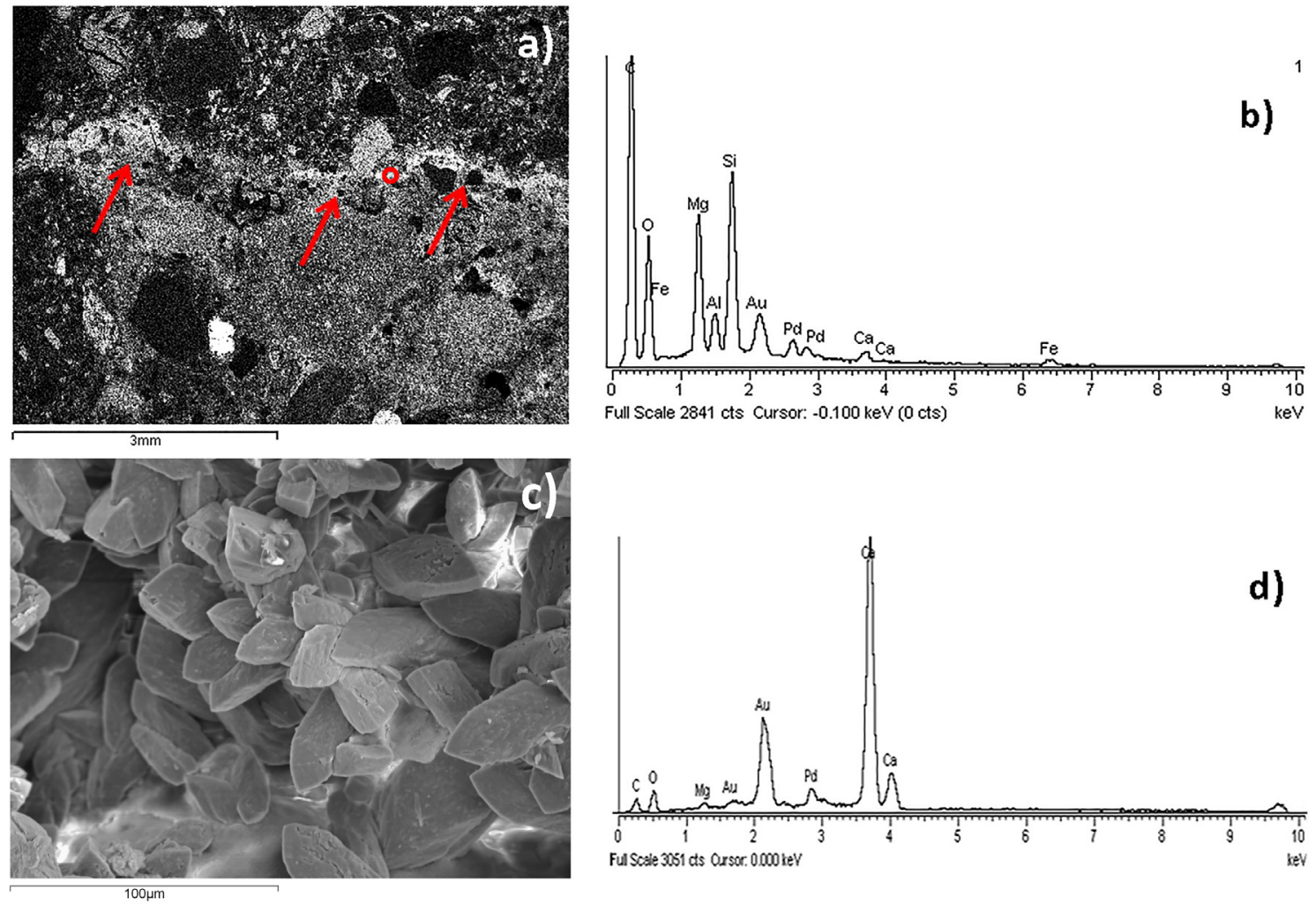

Fig. 10. a) Elemental X-ray map of magnesium in mortar P7 (dotted spot in Fig. 6c); the red arrows indicates the formation of magnesium silicate; b) relative EDS spectrum of the spot within the red circle in a; c) recrystallized calcite inside microcracks in mortar PB1, and d) relative EDS spectrum corresponding to calcite.

Table 5

Mortars composition (mass \%) and binder/aggregate ratio (volume).

\begin{tabular}{|c|c|c|c|c|}
\hline Samples & $\begin{array}{l}\text { Siliceous } \\
\text { Sand }^{1}\end{array}$ & Carbonates $^{2}$ & Soluble Fraction $^{3}$ & Lime:Aggregate ratio \\
\hline $\mathrm{P} 2$ & 46 & 41 & 13 & $\approx 1: 1.5$ \\
\hline P3 & 64 & 26 & 8 & $\approx 1: 3$ \\
\hline P4 & 60 & 28 & 12 & $\approx 1: 3$ \\
\hline P8 & 68 & 23 & 9 & $\approx 1: 3$ \\
\hline
\end{tabular}

1 Insoluble Residue (IR) in nitric acid.

2 Calculated from $\mathrm{CaCO}_{3}$ content (TGA analysis).

3 Soluble Fraction $=100-\sum($ IR + Carbonates $)$.

According to the results in Table 5, a larger quantity of neoformation and/or hydraulic compounds in the mortars can be attributed to the higher values of the soluble fraction (as in the case of mortars P2 and P4). These hydraulic compounds guarantee a better mechanical resistance and durability, when compared to aerial lime mortars [36].

The ideal 1:3 binder:aggregate ratio, recommended by Vitruvius and Plinius [37,38], was respected in mortar P3, P4 and P8; the high binder content in sample P2 can also be attributed to the functional requirements of this mortar (used in the furnace of the thermal baths). In fact, a high binder quantity provides better plasticity, binding and waterproofing to the mortar [25,39].

\subsection{Mortar classification}

Based on the analytical characterization described in the previous sections, mortar samples can be categorised according to their composition, as follows:

a) Aerial lime mortars with siliceous aggregates (mortars P3, P5, P8 and PM): the binder is mostly calcite (21-29\% in weight), with some traces of magnesium carbonates; clay minerals were detected in minimal amount, thus not conferring hydraulic features to the mortars. These mortars were formulated for plasters (applied in the interior of the complex) or renders (in the mausoleum and mill) which do not require waterproofing properties. The accidental addition of residual earth can also explain the poor cohesion and compaction of these mortars.

b) Crushed ceramic-lime mortars (P4, P6 and P7): these mortars have a moderate lime content (26-38\% in weight) and a remarkable amount of brick fragments; these artificial pozzolanic aggregates were added to confer hydraulic properties (and thus improved physical-mechanical properties, i.e. waterproofing) to the coating mortars used in waterbearing structures (e.g. swimming pool, porch), as confirmed also by the high levels of water bound to hydraulic properties (TGA-DTA analysis, Section 3.2).

c) Lime mortars with natural pozzolanic aggregates (P2, PB1 and PB2): these mortars present a calcite content from 33 to $46 \%$ and a matrix with a remarkable amount of clay-rich rock as green shale or schist; these aggregates are typically found in the region of the Pisões archaeological site (Fig. 8) and conferred moderate hydraulic properties to these mortars; addi- 
Table 6

Recommendations on the composition and formulation of repair mortars.

\begin{tabular}{|c|c|c|c|}
\hline Function and location(s) (mortar samples) & $\begin{array}{l}\text { Binder:aggregate } \\
\text { ratio }\end{array}$ & $\begin{array}{l}\text { Mortar dosage (estimated parts, in } \\
\text { volume }^{1} \text { ) }\end{array}$ & Aggregates grain size distribution (\% grain size) \\
\hline Coating mortar - Furnace (P2) & $1: 2$ & $\begin{array}{l}1 \text { hydrated lime } \\
1.2 \text { siliceous sand } \\
0.3 \text { brick powder } \\
0.5 \text { green shale }\end{array}$ & $\begin{array}{l}40 \% \geq 5 \mathrm{~mm} 2.5 \mathrm{~mm} \leq 35 \% \leq 1.25 \mathrm{~mm} 25 \% \leq \\
0.6 \mathrm{~mm}\end{array}$ \\
\hline Coating mortar - Clothing (P3), Rooms (P5) & $1: 3$ & $\begin{array}{l}1 \text { hydrated lime } \\
2.65 \text { siliceous sand }^{*} \\
0.35 \text { residual earth }^{* * *}\end{array}$ & $\begin{array}{l}35 \% \geq 5 \mathrm{~mm} 2.5 \mathrm{~mm} \leq 35 \% \leq 1.25 \mathrm{~mm} 30 \% \leq \\
0.6 \mathrm{~mm}\end{array}$ \\
\hline $\begin{array}{l}\text { Flooring mortar -Porch (P4), Swimming pool } \\
\quad \text { (P7) }\end{array}$ & $1: 3$ & $\begin{array}{l}1 \text { hydrated lime } \\
1.5 \text { siliceous sand } \\
0.9 \text { brick powder } \\
0.6 \text { green shale }\end{array}$ & $\begin{array}{l}40 \% \geq 5 \mathrm{~mm} 2.5 \mathrm{~mm} \leq 30 \% \leq 1.25 \mathrm{~mm} 30 \% \leq \\
0.6 \mathrm{~mm}\end{array}$ \\
\hline Flooring mortar - Swimming pool (P6) & $1: 3$ & $\begin{array}{l}1 \text { hydrated lime } \\
2.25 \text { siliceous sand } \\
0.75 \text { brick powder or fragments }\end{array}$ & $\begin{array}{l}40 \% \geq 5 \mathrm{~mm} 2.5 \mathrm{~mm} \leq 30 \% \leq 1.25 \mathrm{~mm} 30 \% \leq \\
0.6 \mathrm{~mm}\end{array}$ \\
\hline Coating mortar -Mausoleum (P8), Mill (PM) & $1: 3$ & $\begin{array}{l}1 \text { hydrated lime } \\
2.4 \text { siliceous sand } \\
0.3 \text { green shale/schist } \\
0.3 \text { residual earth }\end{array}$ & $\begin{array}{l}45 \% \geq 5 \mathrm{~mm} 2.5 \mathrm{~mm} \leq 30 \% \leq 1.25 \mathrm{~mm}, 25 \% \leq \\
0.6 \mathrm{~mm}\end{array}$ \\
\hline Coating mortar - Dam (PB1, PB2) & $1: 3$ & $\begin{array}{l}1 \text { hydrated lime } \\
2.1 \text { siliceous sand }^{*} \\
0.9 \text { green shale }^{* *}\end{array}$ & $\begin{array}{l}40 \% \geq 5 \mathrm{~mm} 2.5 \mathrm{~mm} \leq 35 \% \leq 1.25 \mathrm{~mm} 25 \% \leq \\
0.6 \mathrm{~mm}\end{array}$ \\
\hline
\end{tabular}

${ }^{1}$ Considering the following bulk densities $(\rho): \rho_{\text {hydrated lime }}=0.4 \mathrm{~g} / \mathrm{cm}^{3}, \rho_{\text {siliceous sand }}=1.4 \mathrm{~g} / \mathrm{cm}^{3}, \rho_{\text {brick powder }}=0.9 \mathrm{~g} / \mathrm{cm}^{3}, \rho_{\text {green shale }}=1.3 \mathrm{~g} / \mathrm{cm}^{3}$.

Commercially available.

** Extracted approximately $4 \mathrm{~km}$ south of the villa (according to the local geological map, Fig. 8).

*** From the soil nearby the archaeological complex.

tionally, traces of ceramic fragments were detected in mortar P2. These lining mortars were also used in hydraulic structures as the furnace of the thermal bath and the dam.

Additionally, sample P1 is likely to be a brick fragment (collected from the thermal bath), due to it physical-chemical properties (high compaction, high Si and Al-based compounds, only traces of calcite).

\subsection{Repair mortars}

The design of repair mortars starts from the chemicalmineralogical characterization of the original mortars [40]. Based on the results obtained in the previous section, it can be seen that the aggregates of the aerial lime-based mortars vary based on their functionality in the architectural structure. In order to formulate compatible and reversible repair mortar, some recommendations are given in Table 6.

A hydrated lime, conceived for conservation purposes, is recommended, as well as the use of high purity and calibrated aggregates (siliceous sand, brick fragment/powder). Natural hydraulic lime (e.g. NHL 3.5), which demonstrated a suitable compatibility with ancient mortars [41], might be considered in substitution of the hydrated lime for the formulation of repair mortars. Additionally, special attention should be paid to the workability and thus applicability of the mortars, by optimising the water:binder ratio of the mortars.

It has to be pointed out that water-bearing structures were finished using the opus signinum and according to the torus principium. In fact, sharp edges of the corners of these surfaces were eliminated, by giving them a curved or bevelled shape. The rounding-off of the edges was meant to guarantee the conservation of the water structure, ad reduce water flow deterioration [8]. This construction technique, which was observed in the furnace of the thermal bath (mortar P2) and in the swimming pool (mortars P6, P7), should be reproduced, if necessary, in order to maintain also their architectonical, engineering and, ultimately, historical value.
However, further physical-mechanical tests are recommended in order to judge the overall performance and compatibility of the repair mortar [40]. Additionally, mortars should be monitored over time (up to 12 months) in order to check the full carbonation of the binder and the durability to weathering agents.

\section{Conclusions}

This work presents an extensive chemical (TGA, SEM-EDS, combustion analysis, potentiometric titration), mineralogical (XRD, petrography) and morphological (optical and petrographic microscopy, SEM) analysis of the ancient mortars from the Roman archaeological site of Pisões. An overview on the composition and conservation state of the mortars and a conservation strategy for the renders and plasters is provided.

Results showed that the composition of the mortars depended on the location and use of each mortar, in accordance with other studies on roman structure in the Iberian Peninsula $[3,5,7,8,10-$ 13].

The mortars have mostly a calcitic matrix (and low percentages of magnesium in some cases), obtained by burning the calcareous stone at temperatures lower than $800-900{ }^{\circ} \mathrm{C}$. A wide variety of local aggregates and ceramic fragments was used for the formulation of the mortars. As a matter of fact, Roman builders may have used, for the production of the binder, the limestone extracted from the nearby quarry of Trigaches, located at $10 \mathrm{~km}$ south of the villa. However, the presence of lime lumps in few mortars (P3, P5) shows that the binder was not perfectly slaked and/or homogeneously mixed with the aggregates. This explains the poor state of conservation of those mortars. On the other hand, other samples (P2, P4, P6, P7) have a good cohesion and state of conservation, which is to be attributed both to their hydraulic properties and high reactivity and quality of the calcitic binder (obtained by a soft burning of the raw limestone, as advised by the Romans) [3].

Natural (siliceous and/or clay-rich rocks) and artificial (crushed brick) pozzolanic additions enhance the formation of hydraulic products, which provide waterproofing properties and higher 
mechanical strength (when compared to regular lime-based mortar).

The formation of hydraulic products and recrystallized calcium carbonate processes promotes a partial pore filling. This can explain the good cohesion, mechanical strength and long-term durability of part of the studied mortars [42]. Additionally, no significant amounts of detrimental compounds (i.e. soluble salts as chlorides and/or sulphates) were detected.

Ultimately, the favourable state of conservation of the mortars can be explained by the careful selection of the raw materials; as a matter of fact, the skilled roman builders had in-depth knowledge of the material features (both in the slaking of lime and in the selection of pozzolanic additives and aggregates) [25].

The data obtained in this paper will be useful in the elaboration of compatible repair mortars and, thus, in the definition of an appropriate conservation strategy on the Pisões archaeological complex.

\section{Conflict of interest}

None.

\section{Acknowledgements}

The authors wish to acknowledge the technical support of the technicians Dora Soares and Paula Menezes for their support in the chemical and microstructural analysis, and acknowledge FCT (Portuguese Foundation for Science and Technology) for the financial support under project DB-HERITAGE - Database of building materials with historical and heritage interest [grant number PTDC/EPH-PAT/4684/2014].

\section{References}

[1] B. Wegemann, ROMANOS - Cidades, Monumentos, Villas e Museus: um guia para visitar o legado romano em Portugal e na Espanha, 5th Edition, 2016 Edições de Arqueologia da tipografos.net.

[2] D. Miriello, D. Barca, A. Bloise, A. Ciarallo, G.M. Crisci, T. De Rose, C. Gattuso, F. Gazineo, M.F. La Russa, Characterisation of archaeological mortars from Pompei (Campania, Italy) and identification of construction phases by compositional data analysis, J. Archaeol. Sci. 37 (2010) 2207-2223.

[3] M.D. Robador, J.L. Perez-Rodriguez, A. Duran, Hydraulic structures of the Roman Mithraeum house, in Augusta Emerita, Spain, J. Archeol. Sci. 37 (2010) $2426-2432$.

[4] J. Marques, H. Ruas, S. Gonçalves, F. Briosa, Guide to the Roman villa of Pisões, Elaborated by the IPPAR (Portuguese Institute for the Architectural Heritage), 2000, Lisbon.

[5] I. Cardoso, M.F. Macedo, F. Vermeulen, C. Corsi, A. Santos Silva, L. Rosado, A. Candeias, A.J. Mirao, A multidisciplinary approach to the study of archaeological mortars from the Town of Ammaia in the Roman Province of Lusitania (Portugal), Archaeometry 56 (1) (2014) 1-24.

[6] A. Santos Silva, J.M. Ricardo, M. Salta, P. Adriano, J. Mirão, A.E. Candeias, S. Macias, Characterization of Roman mortars from the historical town of Mértola, Proceedings of Heritage, International Weathering and Conservation Conference HWC, 2006. Madrid.

[7] A. Santos Silva, M. Paiva, J.M. Ricardo, M. Salta, A.M. Monteiro, A.E. Candeias, Characterisation of Roman Mortars from the Archaeological Site of Tróia (Portugal), Mater. Sci. Forum 514 (2006) 1643-1647.

[8] A. Velosa, J. Coroado, R. Veiga, F. Rocha, Characterisation of roman mortars from Conímbriga with respect to their repair, Mater. Charact. 58 (2007) 12081216.

[9] T. Freire, A. Santos Silva, R. Veiga, J. de Brito, Caracterização de Revestimentos Interiores Antigos Portugueses Technical report, LNEC, Lisbon, 2010.

[10] J. Sanjurjo-Sánchez, M.J. Trindade, R. Blanco-Rotea, R. Benavides Garcia, D. Fernández Mosquera, C. Burbidge, M.I. Prudêncio, M.I. Dias, Chemical and mineralogical characterization of historic mortars from the Santa Eulalia de Bóveda temple, NW Spain, J. Archeol. Sci. 37 (2010) 2346-2351.

[11] C. Genestar, C. Pons, A. Más, Analytical characterisation of ancient mortars from the archaeological Roman city of Pollentia (Balearic Islands, Spain), Anal. Chim. Acta 557 (2006) 373-379.

[12] P. Guerra García, D. Sanz Arauz, F. Vela Cossío, Microscopy and techniques of characterization applied to archaeological work: a proposal of study in hydraulic Roman mortars analysed in Cuenca province (Spain), Proceedings of 3rd Historic Mortar Conference HMC13, Glasgow, 2013.
[13] M.D. Robador, F. Arroyo, Characterisation of Roman coatings from a Roman house in Mérida (Spain), J. Cult. Heritage 14 (2013) 52-58.

[14] R. Veiga, J. Aguiar, A. Santos Silva, F. Carvalho, Methodologies for characterization and repair of mortars of ancient buildings, in: Proceedings of the 3rd International Seminar on Structural Analysis of Historical Constructions, Minho University, Guimarães, Portugal, 2001, pp. 353-362.

[15] B. Middendorf, J.J. Hughes, K. Callebaut, G. Baronio, I. Papayianni, Methods for the characterization of historic mortars- Part 1: Mineralogical characterization, Mater. Struct. 38 (2005) 761-769.

[16] B. Middendorf, J.J. Hughes, K. Callebaut, G. Baronio, I. Papayianni, Methods for the characterization of historic mortars-Part 2: Chemical characterization, Mater. Struct. 38 (2005) 771-780.

[17] A. Santos Silva, T. Cruz, M.J. Paiva, A. Candeias, P. Adriano, N. Schiavon, J.A.P. Mirão, Mineralogical and chemical characterization of historical mortars from military fortifications in Lisbon harbour (Portugal), Environ. Earth Sci. 63 (2011) 1641-1650.

[18] EN 196-2, European Standard, Method of Testing Cement - Part 2: Chemical Analysis of Cement, European Committee for Standardizataon (CEN), 2003.

[19] EN 14629, European Standard, Products and Systems for the Protection and Repair of Concrete Structures. Test Methods. Determination of Chloride Content in Hardened Concrete, European Committee for Standardization (CEN), 2007.

[20] H. Jedrzejewska, Old mortar in Poland: a new method of investigation, Stud Conserv. 4 (5) (1960) 132-138.

[21] F. Casadio, G. Chiari, S. Simon, Evaluation of binder/aggregate ratios in archaeological lime mortars with carbonate aggregate: a comparative assessment of chemical, mechanical and microscopic approaches, Archaeometry 47 (4) (2005) 671-689.

[22] F. Veniale, M. Setti, C. Rodriguez-Navarro, S. Lodola, Role of clay constituents in stone decay processes, Mater. Constr. 51 (2001) 163-182.

[23] A. Bakolas, A. Biscontin, A.E. Zendri, Characterization of structural byzantine mortars by thermogravimetric analysis, Thermochim. Acta 321 (1998) 151 160.

[24] H. Böke, S. Akkurt, B. Ipekoglu, E. Ugurlu, Characteristics of brick used as aggregate in historic brick-lime mortars and plasters, Cem. Concr. Res. 36 (2006) 1115-1122.

[25] M.D. Jackson, J.L. Logan, B.E. Scheetz, D.M. Deocampo, C.G. Cawood, F. Marra, M. Vitti, L. Ungaro, Assessment of material characteristics of ancient concretes, Grande Aula, Market of Trajan, Rome, J. Archeol. Sci. 36 (2009) 2481-2492.

[26] P. Maravelaki-Kalaitazaki, A. Bakolas, A. Moropoulou, Physico-chemical study of Cretan ancient mortars, Cem. Concr. Res. 33 (2003) 651-661.

[27] A. Moropoulou, A. Bakolas, K. Bisbikou, Investigation of the technologies of historic mortars, J. Cult. Heritage 1 (2000) 45-58.

[28] S. Pavía, S. Caro, An investigation of Roman mortar technology through the petrographic analysis of archaeological material, Constr. Build. Mater. 22 (2008) 1807-1811.

[29] M. Mendoça de Oliveira, From Vitruvius's ceramic powder additives to modern restoration, Proceedings of 1st Historic Mortar Conference HMC08 Characterization, Diagnosis, Conservation, Repair and Compatibility, 2008. Lisbon.

[30] P. Adriano, A. Santos Silva, Characteriztion of ancient mortars from the Santa Maria Church (Sé Catedral) in Évora Confidential report 59, Material Departments, LNEC, Lisbon, 2006.

[31] T. Guerreiro, A. Santos Silva, P. Adriano, A. Candeias, J. Mirão, Optical microscopy analysis of mortars from Tagus River 16th and 17th century fortifications, Microsc. Microanal. 14 (2008) 77-80.

[32] J. Elsen, A. Brutsaert, M. Deckers, R. Brulet, Microscopical Studies of ancient mortars from Tournai (Belgium), Mater. Charact. 53 (2004) 289-294.

[33] I. Papayianni, The longevity of old mortars, Mater. Sci. Process. Appl. Phys. A 83 (2006) 685-688

[34] P. Adriano, A. Santos Silva, R. Veiga, J. Mirão, A. Candeias, The importance of SEM-EDS analysis in the study of old mortars, Microsc. Microanal. 14 (2008) $57-60$.

[35] A. Velosa, R. Veiga, The Use of Additivated Lime Mortars for Old Building Rehabilitation - Adapted Testing Methods, CATHEDRAL Project, LNEC, 2004 http://conservarcal.lnec.pt/pdfs/Velosa.pdf.

[36] S. Kramar, V. Zalar, M. Urosevic, W. Körner, A. Mauko, B. Mirtič, J. Lux, A. Mladenović, Mineralogical and microstructural studies of mortars from the bath complex of the Roman villa rustica near Mošnje (Slovenia), Mater. Charact. 62 (2011) 1042-1057.

[37] Vitruvius Pollio, The Ten Books on Architecture, Harvard University Press, Cambridge, 1970

[38] Plinius the Elder, Naturalis Historia - Natural history, The Folio Society Edition, London, 2012

[39] I.A. Meir, C. Freidin, I. Gilead, Analysis of Byzantine mortars from Negev Desert Israel, and subsequent environmental and economic implications, J. Archeol. Sci. 32 (2005) 767-773.

[40] L. Schueremans, O. Cizer, E. Janssens, G. Serré, K. Van Balen, Characterization of repair mortars for the assessment of their compatibility in restoration projects: research and practice, Constr. Build. Mater. 25 (2011) 4338-4350.

[41] J. Elsen, K. Van Balen, G. Mertens, Hydraulicity in historic lime mortars: a review. In: 2nd Historic Mortars Conference HMC2010 and RILEM TC 203RHM Final Workshop 22-24 September 2010, Prague, Czech Republic.

[42] C. Borges, A. Santos Silva, R. Veiga, G. Borsoi, Historical Heritage: A study to conservation. In: Proceeding of VI International Materials Symposium Materiais, 2011, Guimarães, Portugal. 